\title{
Root Growth Responses of Anagallis arvensis of the Tropical Agroecosystem to Coal Smoke Pollution
}

\author{
Mohammad Saquib
}

\begin{abstract}
The effect of coal smoke pollution on the root length, root biomass and net primary productivity of Anagallis arvensis growing in association with wheat cropland was studied at monthly intervals with collections from four selected sites situated at $0.5,2,4$ and $20 \mathrm{Km}$ leeward from a thermal power plant complex. The degree of loss in the root growth increased significantly with decrease in distance from the source of pollution. The trend of loss in the root length was similar in the first (seedling stage) and the second (flowering stage) collections; the adverse effect of pollutants was almost constant up to $4 \mathrm{~km}$ at old stage from the pollution source in the third collection (post-flowering stage), compared with the population at site ' $D$ ' situated at $20 \mathrm{~km}$ leeward from the source of pollution. Root biomass suffered considerably at seedling stage up to $4 \mathrm{Km}$. The trend of loss was almost similar at flowering and post-flowering stages of growth. Root biomass and net primary productivity showed a maximum loss $(-45.8$ to $-74 \%$ and -53.8 to $-76.9 \%$ respectively) at flowering stage. This correlates to high coal consumption and greater release of gaseous pollutants from the power plant during that period. The percent loss in the root growth of $A$. arvensis showed a linear relationship with the distance of the site from the source of pollution at any given stage. Root biomass exhibited a relatively greater degree of dependence ( 59 to $76 \%$ ) on distance than the root length ( 38 to $58 \%$ ).
\end{abstract}

Index Terms-Coal smoke pollution, root growth, net primary productivity, anagallis arvensis, agroecosystem.

\section{INTRODUCTION}

Thermal power plants consume about 34 percent of the total coal produced in India (nearly 180 million tons per year) and contribute about 27 percent to the total pollutants in the air [1]. The current widespread use of coal in the thermal power plant has contributed sizably to degradation of the atmosphere. India has as many as 75 thermal power stations, running on sulphur-rich low-grade bituminous coal and releasing enormous amounts of oxides of sulphur, nitrogen and carbon, various other gases in small quantities, and the particulates [2]. The pollutants emitted from power plants reach the ground at various distances from the emission point depending upon wind direction. The particulates and gaseous pollutants, alone and in combination, can cause serious setbacks to the overall physiology of plants [3]-[7].

The sensitivity of roots to the stress of air pollution has been studied by a number of workers [8]-[13]. The present study examines the root-growth responses of Anagallis

Manuscript received December 30, 2011.

Mohammad Saquib is with the Department of Biological Sciences, Adamawa State University, Mubi, Adamawa State, Nigeria (e-mail: mohammadaqib@hotmail.com). arvensis of the tropical agroecosystem to air pollution.

\section{MATERIALS AND METHODS}

The Kasimpur Thermal Power Plant complex was selected as a source of pollution in the present study. It consists of three power stations with a capacity of $90 \mathrm{MW}$, $210 \mathrm{MW}$ and $230 \mathrm{MW}$ electricity generation capacities. It is located along an irrigation canal about $16 \mathrm{Km}$ north-east of Aligarh city (India). Geographically, the Aligarh district falls between $27^{\circ} 29^{\prime} \mathrm{N}$ and $28^{\circ} 11^{\prime} \mathrm{N}$ latitude and $77^{\circ} 29^{\prime} \mathrm{E}$ and $77^{\circ} 38^{\prime} \mathrm{E}$ longitude, about 187 meters above the sea level. The daily coal consumption and the amounts of oxides of Sulphur, Nitrogen and Carbon released from the power plant complex are shown in Fig. $1 \mathrm{a}$ and $1 \mathrm{~b}$.

Four sites of the wheat crop fields were selected at about $0.5,2,4$ and $20 \mathrm{Km}$ leeward from the source of pollution, along the canal side in downstream direction since the wind blows predominantly in this direction for most part of the year. The four sites, identified as 'A', 'B',' C' and ' $D$ ', respectively, and located in a belt with similar edaphic factors as well as ecological and agricultural conditions, were selected for the present study. The soil at different study sites comprised of loam and clayey loam had a high $\mathrm{p}^{\mathrm{H}}$ and a poor drainage system. The area would experience a dry and tropical monsoon type of climate.

Ten samples of Anagallis arvensis were collected (at seedling to post-flowering stage) arbitrarily from wheat crops at the four selected sites at monthly (January to March) intervals. The roots were washed and measured on a meter scale, oven-dried at $80^{\circ} \mathrm{C}$ for $48 \mathrm{~h}$, and weighed. The data so obtained were analyzed by applying the LSD (Least Significant Difference) in order to know the statistical significance of the changes observed because of pollution stress. To obtain the relative degree of response of the root length and root biomass, at a given growth stage, the per cent differences at sites ' $A$ ', 'B', and ' $\mathrm{C}$ ' as compared with site 'D' (the reference site) were computed (Table-1 \& 2). The net increase in the biomass per root at any stage was divided by the age of the plant to obtain the net primary productivity $\left(\mathrm{mg} \operatorname{root}^{-1} \mathrm{day}^{-1}\right)$. However, the biomass of fine root hair lost during the measurement period was not included in this estimate of root productivity. The plant age as well as the initial biomass was taken to be zero on the first January.

\section{RESULTS}

The data obtained on the average root growth of $A$. arvensis showed a gradual increase with increase in distance from the power plant (Table I and II). Root growth suffered significantly in all the three stages of growth up to $4 \mathrm{Km}$ 
from the source of pollution as compared to the control site 'D', (20 Km away from the source). However, severity of the loss was more prominent at site ' $A$ ' in all the stages. The trend of loss in the root length was similar at the seedling stage (January collection) and flowering stage (February collection) of growth. However, in the postflowering (March collection), the adverse effect of pollutants was constant up to $4 \mathrm{Km}$. Root biomass showed a considerable reduction up to $4 \mathrm{Km}$ from the power plant at the seedling stage. The trend of loss was similar in the flowering and post-flowering stages of plant growth. However, plants were most sensitive in the flowering stage $(-45.8$ to $-74.7 \%)$ of growth (Table II). On the whole, root biomass suffered greater $(-17.5 \%$ to $-74.7 .0 \%)$ than root length $(-24.6 \%$ to $-54.5 \%)$. The percent loss in root growth showed a linear relationship with the distance from the source of pollution at any given stage.

The data summarized in Table III show the daily net primary productivity in standing root biomass in time and space, and the percent loss at site ' $A$ ' , ' $B$ ' and ' $C$ ' compared with that at site ' $\mathrm{D}$ '. The root productivity suffered considerably at seedling and flowering growth stages, up to a distance of $4 \mathrm{Km}$ from the source of pollution. However, the degree of loss was highest $(-53.8$ to $-76.9 \%$ ) in the flowering stage.

The percent dependence of root length and root biomass on distance from the power plant, the correlation coefficient and the linear regression equation are all summarized in Table-4. Both the root length and root biomass showed a significant, positive and high relationship with the distance from the source. Root length showed 38\% - 58\% dependence on the distance from the source, while root biomass exhibited a relatively greater degree $(59-76 \%)$ of dependence. The correlation coefficients for root biomass vs distance and root length vs distance were greater in the flowering and post-flowering stages of plant growth respectively.

\section{Discussion}

The present findings show that the extent of root growth in $A$. arvensis is variable and correlative to distance from power plant, age of the plants, coal-consumption rate and the release of major gases from the power plant. Changes in root growth due to air pollutants have been reported in many species by a number of earlier workers $[14,15,9,16$, $6,12,13]$. The effects on root growth and development are ascribed to imbalance in the carbon partitioning induced by air pollutants $[17,18]$. In the present study, root length suffered greater in seedling and flowering stages of growth, while in the post-flowering stage, the decline was less and almost constant up to $4 \mathrm{~km}$ from the pollution source. [6] noted that the root length of Althea officinalis decreased with increase in plant age under the stress of $\mathrm{SO}_{2}$. The percent reduction in root biomass and net primary productivity of $A$. arvensis increased from seedling to flowering stages and declined at the old stage. $[19,12]$ noted an increase in percent reduction in root growth from seedling to flowering stage of growth of Lolium prenne and Melilotus indicuse, respectively, under air pollution stress.

A linear relationship between plant age and the loss of phytomass caused by air pollution was found to exist in Cicer arietenum [20] and Melilotus indicus [12] .The highest degree of response of root biomass and Net Primary Productivity in the flowering stage may be due to high amount of coal consumption and greater release of major gases from the power plant during that period (See Fig.1a and 1b). Similar correlations were noted in a cropland weed, viz. Melilotus indicus [12] and a waste-land weed, Anagallis arvensis [9]. Earlier workers [21], [22] have also found a decrease in the extent of foliar injury and damage with increasing distance from the source, as observed in the present study.

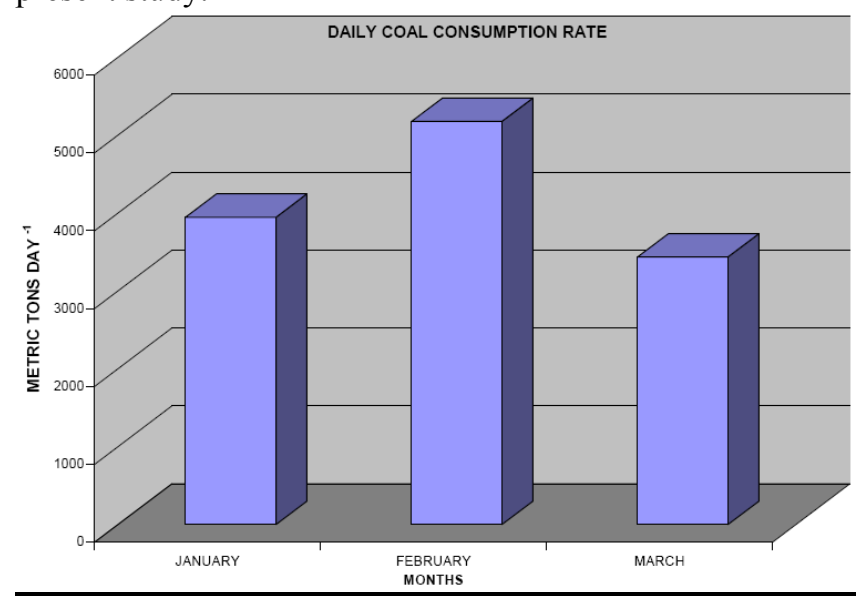

Source: Kasimpur Thermal Power Plant Complex

Fig. 1a

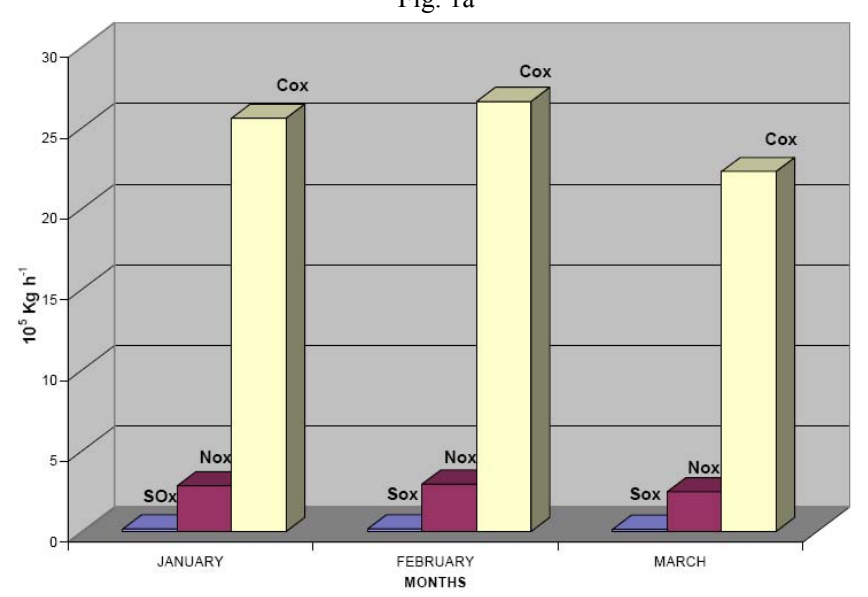

Source: Kasimpur Thermal Power Plant Complex

Fig. 1 b. Sox $=$ Oxides of Sulphur $; \mathrm{NOx}=$ Oxides of Nitrogen $; \mathrm{COx}=$ Oxides of Carbon

TABLE I: AVERAge RoOT LeNGTH Plant ${ }^{-1}$ (CM) IN THE POPULATION OF ANAGALLIS ARVENSIS OF VARYING DISTANCE FROM POLLUTION SOURCE. THE DATA WITHIN PARENTHESIS INDICATE THE PERCENT VARIATION OVER REFERENCE SITE 'D'.

\begin{tabular}{|c|c|c|c|c|c|}
\hline $\begin{array}{c}\text { Sites } \\
\text { Distance }\end{array}$ & $\underset{0.5 \mathrm{~km}}{\mathrm{~A}}$ & $\begin{array}{c}\text { B } \\
2 \mathrm{~km}\end{array}$ & $\begin{array}{c}C \\
4 \mathrm{~km}\end{array}$ & $\begin{array}{c}D \\
20 \mathrm{~km}\end{array}$ & $\begin{array}{c}\text { LSD at } \\
5 \% \text { level }\end{array}$ \\
\hline January & $\begin{array}{c}\mathrm{a} \\
2.0 \pm 0.4 \\
(-54.5)\end{array}$ & $\begin{array}{c}b \\
2.7 \pm 0.5 \\
(-39.6)\end{array}$ & $\begin{array}{c}\mathrm{b} \\
3.1 \pm 0.8 \\
(-30.3)\end{array}$ & $\begin{array}{c}\mathrm{c} \\
4.4 \pm 1.1\end{array}$ & 0.7 \\
\hline February & $\begin{array}{c}\mathrm{a} \\
3.1 \pm 0.8 \\
(-53.3)\end{array}$ & $\begin{array}{c}\mathrm{b} \\
4.3 \pm 0.9 \\
(-34.6)\end{array}$ & $\begin{array}{c}b \\
5.0 \pm 1.5 \\
(-24.6)\end{array}$ & $\begin{array}{c}c \\
6.6 \pm 1.8\end{array}$ & 1.2 \\
\hline March & $\begin{array}{c}\mathrm{a} \\
4.8 \pm 1.2 \\
(-44.2)\end{array}$ & $\begin{array}{c}\mathrm{a} \\
4.9 \pm 1.1 \\
(-42.7)\end{array}$ & $\begin{array}{c}\mathrm{a} \\
5.3 \pm 1.2 \\
(-38.3)\end{array}$ & $\begin{array}{c}c \\
8.6 \pm 1.9\end{array}$ & 1.4 \\
\hline
\end{tabular}


Mean \pm Standard deviation

LSD: Least significant Difference at 5\% level

Figures with the same suffix are not significantly different $(\mathrm{p}>0.05)$ from each other.

The data have been reduced to one decimal place after final calculation.

TABLE II: Average RoOT BIOMASS PLANT ${ }^{-1}$ (MG) IN THE POPULATION OF ANAGALLIS ARVENSIS OF VARYING DISTANCE FROM POLLUTION SOURCE. THE DATA WITHIN PARENTHESIS INDICATE THE PERCENT VARIATION OVER REFERENCE SITE 'D’.

\begin{tabular}{|l|c|c|c|c||l|}
\hline $\begin{array}{l}\text { Sites } \\
\text { Distance }\end{array}$ & $\begin{array}{c}\mathbf{A} \\
\mathbf{0 . 5} \mathbf{k m}\end{array}$ & $\begin{array}{c}\mathbf{B} \\
\mathbf{2 k m}\end{array}$ & $\begin{array}{c}\mathbf{C} \\
\mathbf{4 k m}\end{array}$ & $\begin{array}{c}\mathbf{D} \\
\mathbf{2 0 k m}\end{array}$ & $\begin{array}{l}\text { LSD at 5\% } \\
\text { level }\end{array}$ \\
\hline January & $\mathrm{a}$ & $\mathrm{b}$ & $\mathrm{c}$ & $\mathrm{d}$ & \\
& $\begin{array}{c}1.2 \pm 0.3 \\
(-69.2)\end{array}$ & $\begin{array}{c}1.6 \pm 0.4 \\
(-57.0)\end{array}$ & $\begin{array}{c}3.1 \pm 0.6 \\
(-17.5)\end{array}$ & $3.8 \pm 0.6$ & 0.4 \\
\hline February & $\mathrm{a}$ & $\mathrm{b}$ & $\mathrm{b}$ & $\mathrm{c}$ & \\
& $\begin{array}{c}2.8 \pm 1.4 \\
(-74.7)\end{array}$ & $\begin{array}{c}5.0 \pm 1.4 \\
(-55.2)\end{array}$ & $\begin{array}{c}5.3 \pm 1.6 \\
(-45.8)\end{array}$ & $11.1 \pm 2.1$ & 1.5 \\
\hline March & $\mathrm{a}$ & $\mathrm{b}$ & $\mathrm{b}$ & $\mathrm{c}$ & \\
& $3.2 \pm 0.9$ & $5.1 \pm 1.0$ & $6.0 \pm 1.8$ & $11.3 \pm 2.4$ & 1.6 \\
\hline
\end{tabular}

Mean \pm Standard deviation

LSD: Least significant Difference at 5\% level

Figures with the same suffix are not significantly different $(p>0.05)$ from each other.

Above data have been reduced to one decimal place after final calculation.

TABLE III: AVERAGE DAILY NET PRIMARY PRODUCTIVITY (MG PLANT ${ }^{-1}$ DAY $^{-1}$ ) IN THE POPULATION OF ANAGALLIS ARVENSIS AT VARYING DistancE FROM POLLUTION SOURCE. THE DATA WITHIN PARENTHESIS INDiCATE THE PERCENT VARIATION OVER REFERENCE Site 'D'.

\begin{tabular}{|c|c|c|c||c|}
\hline $\begin{array}{c}\text { Sites } \\
\text { Distance }\end{array}$ & $\begin{array}{c}\mathbf{A} \\
\mathbf{0 . 5} \mathbf{~ k m}\end{array}$ & $\begin{array}{c}\mathbf{B} \\
\mathbf{2} \mathbf{~ k m}\end{array}$ & $\begin{array}{c}\mathbf{C} \\
\mathbf{4} \mathbf{~ k m}\end{array}$ & $\begin{array}{c}\mathbf{D} \\
\mathbf{2 0} \mathbf{~ k m}\end{array}$ \\
\hline January & $\begin{array}{c}0.04 \\
(-66.7)\end{array}$ & $\begin{array}{c}0.05 \\
(-58.3)\end{array}$ & $\begin{array}{c}0.10 \\
(-16.7)\end{array}$ & 0.12 \\
\hline February & $\begin{array}{c}0.06 \\
(-76.9)\end{array}$ & $\begin{array}{c}0.12 \\
(-53.8)\end{array}$ & $\begin{array}{c}0.08 \\
(-69.2)\end{array}$ & 0.26 \\
\hline March & $\begin{array}{c}0.01 \\
(+66.7)\end{array}$ & $\begin{array}{c}0.003 \\
(+50.0)\end{array}$ & $\begin{array}{c}0.02 \\
(+233.3)\end{array}$ & 0.006 \\
\hline
\end{tabular}

Above data have been reduced to two decimal place for absolute values and to one decimal place for percent variation.

TABLE IV: CORRELATION COEFFICIENT (R), PERCENT DEPENDENCE (D) AND LINEAR REGRESSION EQUATION OF ROOT LENGTH AND ROOT BIOMASS WITH REFERENCE TO DISTANCE FROM THE SOURCE OF POLLUTION.

\begin{tabular}{|l|c|c|c||c|}
\hline Months & Parameters & $\begin{array}{c}\text { Correlation } \\
\text { coefficient } \\
(\mathbf{r})\end{array}$ & $\begin{array}{c}\text { Percent } \\
\text { dependence } \\
\mathbf{( \% d )}\end{array}$ & $\begin{array}{c}\text { Linear } \\
\text { regression } \\
\text { equation } \\
(\hat{\mathbf{Y}}=\mathbf{a}+\mathbf{b x})\end{array}$ \\
\hline January & $\mathrm{R} \mathrm{L}$ & $0.74^{* *} \pm 0.11$ & 55 & $2.33+0.11 \mathrm{x}$ \\
& $\mathrm{R} \mathrm{B}$ & $0.77^{* *} \pm 0.10$ & 59 & $1.67+0.11 \mathrm{x}$ \\
\hline \multirow{2}{*}{ February } & $\mathrm{R} \mathrm{L}$ & $0.62^{* *} \pm 0.13$ & 38 & $3.80+0.14 \mathrm{x}$ \\
& $\mathrm{R} \mathrm{B}$ & $0.87^{*} \pm 0.08$ & 76 & $3.50+0.39 \mathrm{x}$ \\
\hline March & $\mathrm{R} \mathrm{L}$ & $0.76^{* *} \pm 0.11$ & 58 & $4.58+0.20 \mathrm{x}$ \\
& $\mathrm{R} \mathrm{B}$ & $0.86^{* *} \pm 0.08$ & 74 & $3.93+0.38 \mathrm{x}$ \\
\hline
\end{tabular}

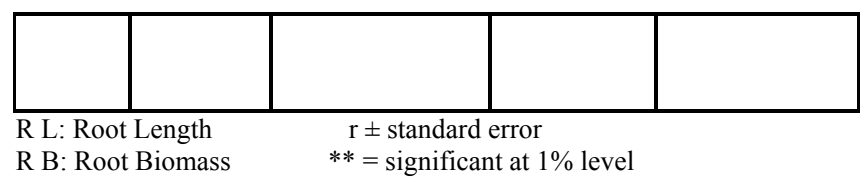

\section{REFERENCES}

[1] CPCB, Delhi Pollution Statistics, Central Pollution Control Board, New-Delhi, India, 1995.

[2] M. Iqbal, P. S Srivastava, T. O. Siddiqi, "Anthropogenic stresses in the environment and their consequences," In Environmental Hazards: Plants and People, M. Iqbal et al.(eds), CBS Publishers, New Delhi. 2000, pp 1-37.

[3] D. T. Tingey and R.A. Reinert, "The effect of ozone and sulphur dioxide singly and in combination on plant growth," Environ. Pollut. volume 9, issue 2, pp. 117-125, 1975.

[4] T .W. Ashenden and I. A. D. Williams, "Growth reduction in Lolium multiflorum Lam. and Phleum pratense L. as a result of sulphur dioxide and nitrogen dioxide pollution," Environ.Pollut. vol. 21, issue 2, pp. 131-139, 1980.

[5] B. Dhir, Mahmooduzzafar, T. O. Siddiqi, and M. Iqbal, "Stomatal and photosynthetic responses of Cichorium intybus leaves to sulphur dioxide treatment at different stages of plant development," J Plant Biol, vol. 44, pp. 97-102, 2001.

[6] B. Wali, Mahmooduzzafar, M. Iqbal. Plant growth, stomatal response, pigments and photosynthesis of Althea officinalis as affected by $\mathrm{So}_{2}$ stress. Ind. J.Plant Physiol. 2004, 9: 224-233.

[7] M. Iqbal, J. Jura-Morawiec, W. Wioch, and Mahmooduzzafar, "Foliar characteristics, cambial activity and wood formation in Azardirachta indica A. Juss. as affected by coal-smoke pollution," Flora, vol. 205, pp. 61-71, 2010.

[8] A. K. M. Ghouse and M. Saquib, "Growth responses of some weeds of an agroecosystem to air pollution," Acta. Bot .Indica, vol. 14, pp. 234-235, 1986.

[9] F. A. Khan, and A. K. M. Ghouse, "Root growth responses of Anagallis arsenic L., Primulaceae to air Pollution," Environ. Pollut, vol. 52, pp. 281-288, 1988.

[10] A. Malibari, Z. Ahmad, and M. Saquib, "Effect of air pollution on Gnaphalium Pensylvanicum wild. A cropland weed," Geobios, vol. 18, pp. 7-10, 1991.

[11] M. Saquib and F. A. Khan, "Air pollution impacts on the growth and reproductive behaviour of mustard," J. Environ. Biol, vol. 20, pp. 107-110, 1999.

[12] M. Saquib, "Root Growth Responses of Melilotus indicus (L.) All. (Papilionaceae) of tropical agroecosystem to air pollution," Ecoprint, vol. 16, pp. 29-34, 2009.

[13] M. Saquib, A. Ahmad, and K. Ansari, "Morrphological and phsiological responses of Croton bonplandianum Baill. to air pollution," Ecoprint, vol. 17, pp. 35-41, 2010.

[14] V. Mejstrik. The influence of low $\mathrm{SO}_{2}$ concentration on growth reduction of Nicotiana tabacum L.W. Samsum and cucumis sativus L. cv Unikat. Environ. Pollut, vol. 21, pp.73-76, 1980.

[15] W. Swannapinunt and T. T. Kozlowski, "Effect of sulphur dioxide on transpiration, chlorophyll content, growth and injury in young seedlings of woody angiosperms," Can. J. For. Res, vol. 10, pp. 178$181,1980$.

[16] N. Kumar. Response of Vigna radiata to $\mathrm{SO}_{2}$ and $\mathrm{NO}_{2}$ pollution. Act. Bot. Indica, vol. 14, pp. 139-144, 1986.

[17] D. T. Tingey, R. A. Reinert., J.A.Dunning, and W. W. Heck, "Vegetation injury from the interaction of nitrogen dioxide and sulphur dioxide," Phytopathol, vol. 61, pp. 1506-1511, 1971.

[18] M. R. Khan and M. W. Khan, "The interaction of $\mathrm{SO}_{2}$ and root knot nematode on tomato," Environ. Pollut, vol. 81, pp. 91-102, 1993.

[19] J. N. B. Bell, A. j. Rutter, and J. Relton, "Studies on the effects of low level of sulphur dioxide on the growth of Lolium Perenne," New Phytol, vol. 83, pp. 627-643, 1976.

[20] P. S. Dubey and K. Pawar. Air Pollution and plant response center. In: D. N. Rao et al. (eds), "Perspectives in environmental botany," vol.1, Lucknow, Print House, India, pp.101-118, 1985.

[21] E. R. de Ong, "Injury to apricot leaves from fluorine deposit," Phytopathol, vol. 36, pp. 469- 471, 1946.

[22] B. Lal and R. S Ambasht, "Fluoride accumulation in a deciduous forest tree species in the neighborhood of an aluminum factory," Indian J. Forestry, vol. 4, pp. 261-264, 1981. 
Mohammad Saquib was born in Gaya (Bihar) India on the $4^{\text {th }}$ September, 1960. He obtained his B.Sc (1980), M.Sc (1983), M.Phil (1984) and Ph.D (1989) degree from Aligarh Muslim University, Aligarh (UP), India. He has about 25 years of teaching and research experience from various countries (India, Kenya, Nepal, Maldives, Guyana (South-America), and Nigeria). Currently, he is Professor and Head, Department of Biological Sciences in Admawa State University, Mubi, Nigeria. His research Interest is Production Ecology, Ecological Physiology, Ecological Anatomy and Environmental Pollution.

Prof. Mohammad Saquib is life member of Indian Botanical Conferece, Indian Botanical Society and Ecological Scociety(Nepal). 